\title{
Improving the Face Validity of Self-Report Scales through Cognitive Interviews Based on Tourangeau Question and Answer Framework: A Practical Work on the Nursing Talent Identification Scale
}

\section{Farzaneh Bagheriyeh}

Tabriz University of Medical Sciences

Akram Ghahramanian

Tabriz University of Medical Sciences

Leila Valizadeh

Tabriz University of Medical Sciences

Vahid Zamanzadeh ( $\square$ zamanzadeh@tbzmed.ac.ir)

Tabriz University of Medical Sciences

\section{Research Article}

Keywords: cognitive interviewing, face validity, instrument development, nursing talent

Posted Date: June 7th, 2021

DOl: https://doi.org/10.21203/rs.3.rs-587444/v1

License: (c) (1) This work is licensed under a Creative Commons Attribution 4.0 International License.

Read Full License 


\section{Abstract}

Background The Nursing Talent Identification self-report Scale is a recently developed to assess the fit of nursing applicants' characteristics for the profession. In such scales, respondents may perceive items in a variety of ways. Hence, while developing such scales, cognitive interviews are used to identify problematic and ambiguous items. The present study aimed to determine how respondents understand and answer to items through cognitive interviews to assess the user-friendliness of the scale and increase its face validity.

Methods In this Qualitative-descriptive study, Tourangeau's four-stage question and answer model was used as a theoretical framework. The participants included 20 first-year nursing students from three western provinces of Iran.. Data were collected through thinking aloud and concurrent and retrospective verbal probing methods. For data analysis, the framework proposed by d'Ardenne and Collins (2015) was use.

Results Through conducting 20 interviews with the participants, problems related to item comprehension, information retrieval, judgment and reporting appropriate answers were identified. Based on the results, out of 95 items, 20 items were modified. The 'instructions' section of the scale was also revised by making the necessary explanations and providing an example.

Conclusions Cognitive interview was effective in identifying problematic items of the Nursing Talent Identification Scale. Although cognitive interviewing is very time-consuming and costly, using this method ensures that the scale has the necessary validity to assess the suitability of nursing applicants to the characteristics of the profession.

\section{Background}

The human resources of each discipline need specific talents and individual characteristics based on the philosophy of the discipline and the professional context $(1,2)$. Identifying talented individuals is critical to improve organizational performance (3). Achieving the philosophy and goals of the nursing profession requires the fit of nurses' talents with the characteristics of the profession; and this ultimately improves the health of society (3). Nurses have a wide range of roles and responsibilities, including care, support, protection, coordination, and training ones. Performing such activities and tasks requires special talents and characteristics in nurses (4). The Nursing Talent Identification Scale is a self-report questionnaire with 54 items, which aims to identify the nursing talents of applicants willing to enter the profession. In this way, the most suitable individuals are employed, which results in job satisfaction and guarantees the quality of nursing care provided by nurses after employment.

An instrument that aims to measure a subjective concept like aptitude has to be constructed carefully. In order for researchers to judge the quality of the instrument, the necessary information about the development process and psychometric properties of the instrument must be provided (5). In selecting health measurement instruments, three characteristics of the instrument including validity, reliability, and 
responsiveness should be considered (6). One of the important types of validity in instrument development is face validity (7). Face validity means that the target population considers all instrument items as relevant. If the participants feel that a measurement lacks face validity, they are likely to withdraw to participate in a study $(5,8)$. Therefore, it has been suggested that participants need to be included in the process of developing self-reporting instruments (6). The validity of self-administered instruments can be threatened by three components, including comprehension problems, validity problems, and processing difficulties (9). The more effort is put into building validity, the greater the trustworthiness of the instrument. For this purpose, mixed methods including quantitative method (item impact index) (10) and qualitative method (cognitive interview) should be used to determine face validity $(5,11)$.

Cognitive interview is used to determine how respondents understand and respond to instrument items $(12,13)$. Researchers can identify the problems in the questionnaire through conducting semi-structured interviews with the target population and make the necessary corrections to facilitate responding to the items (14). This leads to a reduction in incomplete data collection and response error (15). Thinking aloud and verbal probing are common techniques in cognitive interviewing $(16,17)$. In the thinking aloud method, respondents are requested to express their thoughts when finding answers to the items. The verbal probing technique can be concurrent or retrospective, in other words, it can be performed during or after completing the questionnaire. In the concurrent probing, the respondent presents a verbal argument of his / her thoughts while answering the instrument. In the retrospective probing, after the respondent has answered the items, he/she engages in the given answers and expresses the problems in them verbally. Both methods are recommended $(17,18)$.

The Nursing Talent Identification scale has been newly developed to measure the fit of nursing applicants' characteristics with the profession. In such scales, respondents may perceive items in a variety of ways. When developing such scales, cognitive interview is used to identify problematic and ambiguous items (12). The present study aimed to determine how respondents perceive and respond to items through cognitive interviews to assess the user-friendliness of the scale and increase its face validity.

\section{Methods}

\section{The study design}

The present descriptive qualitative study is part an approved doctoral dissertation at Tabriz University of Medical Sciences, Iran. The theoretical framework of the study is comprised of Tourangeau's four-stage question and answer model. This model includes examining the respondent's comprehension of items, information retrieval, the respondent's judgment to find the answer and reporting the appropriate response (19). Based on this model, problems of misinterpretation, missing or excessive details, incomplete recalling and social desirability of the instrument are identified (20).

\section{Participants and Setting}


The participants of this study included 20 first-year nursing students from Nursing and Midwifery Schools in three large provinces in western Iran. Sampling was done using purposive sampling up to data saturation.

\section{Data Collection}

Cognitive interviews were conducted with the participants in the Nursing and Midwifery Schools. The probing questions used in the interview process are listed in Table 1. To collect data, the think-aloud and concurrent and retrospective verbal probing methods were used (21). During the completion of the instrument, the behavior of the respondents was observed and notes were taken about skipping items, changing the response of the items, scale-related problems, and hesitations when responding. Participants were requested to think aloud as they completed the scale and to tell the interviewer whatever came to their mind. Semi-structured interviews were also conducted with the aim of exploring clarity, comprehensibility of items and appropriate face validity of the scale. Each interview lasted approximately 40 to 50 minutes $(11,21)$. When obtaining informed consent, the interviewer provided the participants with the necessary explanations about both of the interviewing techniques and thinking aloud. The interviews were audio-recorded so that the interviewer could concentrate on the interviews and not be distracted by taking notes.

\section{Table 1: probing Questions Used in the Cognitive Interviews}

\begin{tabular}{|c|l|}
\hline Types of probes & \multicolumn{1}{c|}{ Sample probing Question } \\
\hline General probes & $\begin{array}{l}\text { What do you think of the scale (order of items, font size and item } \\
\text { length, etc.) }\end{array}$ \\
\hline Observation probes & $\begin{array}{l}\text { Why did you not answer this item? } \\
\text { Why did you change your answer? } \\
\text { I noticed you are hesitant in your answer. Tell me, what were you } \\
\text { thinking? }\end{array}$ \\
\hline $\begin{array}{c}\text { Comprehension } \\
\text { probes }\end{array}$ & $\begin{array}{l}\text { What do you think this item means? } \\
\text { Can you explain the meaning of this item in your own words? } \\
\text { What is the meaning of this word in this item? }\end{array}$ \\
\hline Retrieval probes & How did you choose the answer to this item? \\
\hline Comfort probes & Did you feel uncomfortable when answering any items? \\
\hline Content probes & $\begin{array}{l}\text { Is this item relevant for assessing nursing aptitude? } \\
\text { Is there any missing item to identify nursing aptitude? }\end{array}$ \\
\hline
\end{tabular}

\section{Ethical Considerations}

This study is part of an approved doctoral dissertation in Nursing at Tabriz University of Medical Sciences, Iran. The study protocol was approved by the Ethics Committee of the University (IR.TBZMED.REC.1397.583). Prior to the study, the objectives of the study were explained to the participants and written consent to participate in the study and audio-recording of the interviews was obtained from all participants. 


\section{Data Analysis}

Data analysis was performed based on the proposed framework for analyzing cognitive interviews. First, the transcript of each interview was read several times by a researcher to gain a full understanding of the text of the interviews. This helped to identify the main problems of the items from the text of the interviews. Each item was then placed in a separate matrix with eight columns. The column headings were based on the framework proposed by d'Ardenne and Collins (2015) as well as common problems identified in the items from the interviews, including respondent details, survey answers, findings from observations and think-aloud method, general probes, comprehension probes, retrieval probes, comfort probes, and other findings $(22,23)$ (Table 2$)$. After analyzing the data, the findings were discussed with the members of the research team in a panel session.

Table 2: Example of an Empty Matrix for Item 7

\begin{tabular}{|c|c|c|c|c|c|c|c|}
\hline \multicolumn{7}{|c|}{ Item 7: I promptly notify an error when it needs to be corrected. } \\
\hline $\begin{array}{c}\text { Respondent } \\
\text { details (ID, } \\
\begin{array}{c}\text { age, } \\
\text { and } \\
\text { gender) }\end{array}\end{array}$ & $\begin{array}{c}\text { Survey } \\
\text { answer }\end{array}$ & $\begin{array}{c}\text { Thinking } \\
\text { aloud/ } \\
\text { observations }\end{array}$ & $\begin{array}{c}\text { General } \\
\text { probes }\end{array}$ & $\begin{array}{c}\text { Comprehension } \\
\text { probes }\end{array}$ & $\begin{array}{c}\text { Retrieval } \\
\text { probes }\end{array}$ & $\begin{array}{c}\text { Comfort } \\
\text { probes }\end{array}$ & Other \\
\hline & & & & & & & \\
\hline
\end{tabular}

\section{Results}

The mean age of participants was 20 years (standard deviation [SD] = 2.5) and $11(57.89 \%)$ of them were female. The problems related to the general aspects of the scale, misinterpretation, missing or excessive details, and incomplete item recalling were identified and corrected. Based on the results, out of 95 items, 20 items were revised. Findings were reported based on Tourangeau's four-stage question and answer model (19). Table 3 illustrates the results of the cognitive interview.

\section{Comprehension (Assessing the Respondent's Comprehension of Items)}

The participants provided detailed feedbacks about the problematic items as follows:

Participants did not interpret item 31 ["I am in contact with many people"] in the intended manner. The students reported that the item could be associated with any communication and was incomprehensible to them. They pointed out that "why one should interact with everyone" (P.12). Thus, according to the participants, this item was changed to: "I have good social relationships with others". In item 34, ["I am an eloquent and audible speaker"], the participants reported that "the words eloquent and audible have difficult meaning" (P.3). Meanwhile, some participants expressed that: "This item implies speaking frankly" (P.11). Therefore, this item was also modified as follows: "I speak to others in a simple and understandable way". In item 72 ["I can do a lot of things without feeling tired"], the participants stated that this item looks a bit unusual. They stated that "Surely a lot of work tires a person. It is better to say 
that I get tired quickly with the least amount of work" (P.7). This item was changed according to the participants. In item 85 ["I evaluate the situations with a broad view and through considering the relationships between the components"], the participants reported: "I did not understand what you mean by 'the relationships between the components'; it is vague" (P.8). The item was modified as follows: "I try to consider all aspects of a problem". In item 93 ["I am slow in performing my tasks accurately"], the participants' perception was that "To do things accurately, you must be slow"(P.18), while this was completely different from the intended meaning of the research team. The participants also stated that "The words 'accurate' and 'slow' imply opposite meanings and make the sentence difficult to understand" (P.17). The item was modified as follows: "While I am fast, I am careful enough when doing things". In item 94 ["I respond quickly to visual and auditory stimuli such as sound and light'], the participants' comprehension was negative and different from the research team. Their perception was that "This item means that they are bothered by sound and light"(P.5). The item was modified as follows: "I use my senses to be aware of my surroundings".

\section{Information Retrieval (determination and how to find the answer to an item)}

This component evaluates participants' responses based on the strategies they use when responding to the item. During the interview with the participants, no problems with information retrieval were identified while responding to the items. Participants retrieved the past and present information from their memory to respond to the items. They constantly thought about their actions and behaviors during these periods, and then responded to the items.

\section{Judgment (respondent's judgment to find the answer)}

Many participants did not interpret item 7 ["I promptly notify an error when it needs to be corrected"] in the intended manner and there were different interpretations. Participants reported that "It is not clear whether the error was made by the individual or other people" (P.9). The item was corrected as follows: "If I make a mistake that needs to be corrected, I report it immediately".

In item 87 ["I pay attention to important details in doing things compared to others"], the participants stated that "A person may be much more precise (being very meticulous is not really needed in nursing profession) compared to the respondent" (P.16). When rewriting this item, 'Compared to' was removed.

\section{Response (choose answer options or find the right words to respond to the item)}

Participants were asked about the usefulness of the questionnaire guide. They suggested that how to respond to items be mentioned with an example in the scale guide. Participants were also asked to comment on the appropriateness of the item response options. Participants agreed on a five-point Likert scale (strongly agree to strongly disagree) to respond to items. They reported answers such as "they are reasonable"(P.13) or "did not notice a problem" (P.8). However, some participants suggested that the scale be reduced to only two or three answer options: "it is sufficient to ask to agree or disagree". "There is no need for strongly agree or strongly disagree" (P.11). Many participants preferred that the five-point Likert 
scale was easier and more accurate than the two or three-point Likert scale. The interviewer observed that participants had difficulty responding to negative items. This was especially evident in item 83: "I do not insist on my wrong ideas and opinions". This item was reviewed and rewritten with an affirmative sentence.

The participants were requested to comment on the usefulness of the scale guide. They suggested that the way of responding to the items be mentioned with an example in the guide section. Participants were also asked to comment on the appropriateness of the item response options. They agreed on a five-point Likert scale (strongly agree to strongly disagree) to respond to the items. They reported answers such as "They are reasonable" (P.13) and "I did not notice a problem" (P.8). However, some participants suggested that the answer options of the scale be reduced to two or three options: "I agree' and 'I disagree' options are OK and there is no need for 'strongly agree' or 'strongly disagree' options"(P.11). Meanwhile, many participants preferred that the five-point likert scale was easier and more accurate than the two- or threepoint likert scale.

In addition, the participants had difficulty responding to negative items. This was especially evident in item 83: "I do not insist on my wrong ideas and opinions". This item was rewritten with an affirmative sentence.

Table 3: Problematic Items and Corrections made Based on Participant Feedback 


\begin{tabular}{|c|c|c|c|}
\hline $\begin{array}{c}\text { Item } \\
\text { no. }\end{array}$ & Problematic items & Interview findings & $\begin{array}{l}\text { Modifications } \\
\text { made to the } \\
\text { items }\end{array}$ \\
\hline 2 & $\begin{array}{lr}\text { I try to perform the } \\
\text { assigned } & \text { tasks } \\
\text { correctly } & \text { and } \\
\text { completely. } & \end{array}$ & $\begin{array}{l}\text { What does 'assigned' mean? I did not } \\
\text { understand the meaning of this word. }\end{array}$ & $\begin{array}{l}\text { I try to do my } \\
\text { tasks correctly } \\
\text { and completely. }\end{array}$ \\
\hline 7 & $\begin{array}{l}\text { I promptly notify an } \\
\text { error when it needs } \\
\text { to be corrected. }\end{array}$ & $\begin{array}{l}\text { It is vague; do you mean a mistake by me or } \\
\text { others? }\end{array}$ & $\begin{array}{l}\text { If I make a } \\
\text { mistake that } \\
\text { needs to be } \\
\text { corrected, I } \\
\text { notify you } \\
\text { immediately. }\end{array}$ \\
\hline 11 & $\begin{array}{lr}\text { I easily adapt } & \text { to an } \\
\text { environment } & \text { with } \\
\text { strict rules and } \\
\text { regulations. }\end{array}$ & $\begin{array}{l}\text { Putting the words 'easy' and 'strict' together } \\
\text { makes it difficult to understand the meaning. } \\
\text { The word 'strict' gives a negative impression } \\
\text { and the image of a military camp comes to } \\
\text { my mind. What is meant by 'strict } \\
\text { regulations'? }\end{array}$ & $\begin{array}{l}\text { I can comply } \\
\text { with workplace } \\
\text { rules and } \\
\text { regulations. }\end{array}$ \\
\hline 12 & $\begin{array}{l}\text { In my view, it is } \\
\text { important to observe } \\
\text { the rules and } \\
\text { regulations. }\end{array}$ & $\begin{array}{l}\text { Why don't you measure pragmatism? You are } \\
\text { measuring the view, but action is more } \\
\text { important. }\end{array}$ & $\begin{array}{l}\text { I respect the } \\
\text { rules and } \\
\text { regulations. }\end{array}$ \\
\hline 18 & $\begin{array}{l}\text { I enjoy caring for } \\
\text { others. }\end{array}$ & $\begin{array}{l}\text { It reminded me of taking care of something. } \\
\text { Rewrite it as: "I enjoy taking care of others". } \\
\text { Delete the word 'for'. }\end{array}$ & $\begin{array}{l}\text { I enjoy taking } \\
\text { care of others. }\end{array}$ \\
\hline 19 & $\begin{array}{l}\text { While dealing } \text { with } \\
\text { people in pain, I try } \\
\text { to alleviate their } \\
\text { suffering. }\end{array}$ & $\begin{array}{l}\text { I did not understand the meaning of } \\
\text { alleviation. Can you express it with a clearer } \\
\text { meaning? }\end{array}$ & $\begin{array}{l}\text { While dealing } \\
\text { with people in } \\
\text { pain, I try to } \\
\text { reduce their } \\
\text { suffering. }\end{array}$ \\
\hline 20 & $\begin{array}{l}\text { I feel obligated to } \\
\text { care for and support } \\
\text { people in need and } \\
\text { the helpless. }\end{array}$ & $\begin{array}{l}\text { The word 'obligated' implied compulsion and } \\
\text { it did not make me feel good. Maybe it would } \\
\text { be better to use the word 'willing' instead of } \\
\text { it. } \\
\text { The item is long and difficult to understand; } \\
\text { I read it three times to find out the meaning. }\end{array}$ & $\begin{array}{l}\text { I consider it my } \\
\text { moral } \\
\text { responsibility } \\
\text { to support the } \\
\text { needy and } \\
\text { disabled. }\end{array}$ \\
\hline 23 & $\begin{array}{l}\text { I listen to others with } \\
\text { interest. }\end{array}$ & $\begin{array}{l}\text { Which conversations do you mean? Who do } \\
\text { you mean by others? Do you mean friendly } \\
\text { chat? }\end{array}$ & $\begin{array}{lr}\text { I } & \text { listen } \\
\text { carefully } & \text { to } \\
\text { someone } & \\
\text { speaking. }\end{array}$ \\
\hline 31 & $\begin{array}{l}\text { I am in contact with } \\
\text { many people. }\end{array}$ & $\begin{array}{l}\text { It is associated with any kind of } \\
\text { communication. It gives different meanings. } \\
\text { Interact with everyone? Why interact with } \\
\text { everyone? Have a lot of friends? }\end{array}$ & $\begin{array}{l}\text { I have good } \\
\text { social } \\
\text { relationships } \\
\text { with others. }\end{array}$ \\
\hline 33 & $\begin{array}{lr}\text { I can } & \text { change } \\
\text { people's beliefs and } \\
\text { attitudes }\end{array}$ & $\begin{array}{l}\text { It implied religious beliefs to me. Why do I } \\
\text { have to change people's religious beliefs? }\end{array}$ & $\begin{array}{l}\text { I can change } \\
\text { people's views } \\
\text { and attitudes } \\
\text { by providing }\end{array}$ \\
\hline
\end{tabular}




\begin{tabular}{|c|c|c|c|}
\hline & $\begin{array}{l}\text { providing logical } \\
\text { explanations. }\end{array}$ & & $\begin{array}{l}\text { logical } \\
\text { explanations. }\end{array}$ \\
\hline 34 & $\begin{array}{l}\text { I am an eloquent and } \\
\text { audible speaker. }\end{array}$ & $\begin{array}{l}\text { Two meanings came to my mind: 'to speak } \\
\text { bluntly' and 'to speak frankly'. }\end{array}$ & $\begin{array}{l}\text { I speak to } \\
\text { others in a } \\
\text { simple and } \\
\text { understandable } \\
\text { way }\end{array}$ \\
\hline 41 & $\begin{array}{l}\text { I listen to the views } \\
\text { of the opposition. }\end{array}$ & $\begin{array}{l}\text { It is vague and distracting. If you mean } \\
\text { teamwork, then add the word } \\
\text { 'in teamwork' or 'collective decision'. }\end{array}$ & $\begin{array}{l}\text { I listen to the } \\
\text { views of the } \\
\text { opposition in } \\
\text { teamwork. }\end{array}$ \\
\hline 47 & $\begin{array}{l}\text { Without judging, I } \\
\text { see things from the } \\
\text { perspective } \\
\text { others. }\end{array}$ & $\begin{array}{l}\text { This sentence was difficult to understand } \\
\text { and participants had a long pause to respond } \\
\text { to the item. }\end{array}$ & $\begin{array}{l}\text { I can } \\
\text { understand the } \\
\text { problems of } \\
\text { others without } \\
\text { judging. }\end{array}$ \\
\hline 55 & $\begin{array}{l}\text { When others are } \\
\text { aggressive, I calmly } \\
\text { listen to them. }\end{array}$ & $\begin{array}{l}\text { The sentence is unusual. You cannot be calm } \\
\text { in aggressive situations, but the person tries } \\
\text { to behave calmly. }\end{array}$ & $\begin{array}{l}\text { When others } \\
\text { are aggressive, } \\
\text { I try to listen to } \\
\text { them calmly. }\end{array}$ \\
\hline 72 & $\begin{array}{l}\text { I can do a lot of } \\
\text { things } \\
\text { feeling tired. }\end{array}$ & $\begin{array}{l}\text { It is somehow unusual or in other words } \\
\text { exaggerated. It is an abnormal expectation. } \\
\text { Certainly, a lot of work tires a person. }\end{array}$ & $\begin{array}{lr}\text { I get } & \text { tired } \\
\text { quickly } & \text { with } \\
\text { the } & \text { least } \\
\text { amount } & \text { of } \\
\text { work. } & \end{array}$ \\
\hline 83 & $\begin{array}{l}\text { I do not insist on my } \\
\text { wrong ideas and } \\
\text { opinions. }\end{array}$ & $\begin{array}{l}\text { The sentence is negative and confusing. I } \\
\text { had a problem answering this question. }\end{array}$ & $\begin{array}{l}\text { I insist on my } \\
\text { wrong ideas } \\
\text { and opinions. }\end{array}$ \\
\hline 85 & $\begin{array}{l}\text { I evaluate the } \\
\text { situations with a } \\
\text { broad view and } \\
\text { through considering } \\
\text { the relationships } \\
\text { between the } \\
\text { components. } \\
\end{array}$ & $\begin{array}{l}\text { It seemed a little vague; I did not understand } \\
\text { the relationship between the components. }\end{array}$ & $\begin{array}{lr}\text { I try } & \text { to } \\
\text { consider } & \text { all } \\
\text { aspects of } & \text { a } \\
\text { problem. } & \end{array}$ \\
\hline 87 & $\begin{array}{lrr}\text { Compared } & \text { to } & \text { other } \\
\text { people, } & \text { I } & \text { pay } \\
\text { attention } & \text { to } \\
\text { important } & \text { details } \\
\text { when doing things. }\end{array}$ & $\begin{array}{l}\text { 'Compared to other people' can be omitted } \\
\text { from the beginning of the sentence. A person } \\
\text { may be much more precise (being very } \\
\text { meticulous is not really needed in nursing } \\
\text { profession) compared to the respondent. }\end{array}$ & $\begin{array}{l}\text { I pay attention } \\
\text { to important } \\
\text { details when } \\
\text { doing things. }\end{array}$ \\
\hline 93 & $\begin{array}{l}\text { I } \text { am slow in } \\
\text { performing my tasks } \\
\text { accurately. }\end{array}$ & $\begin{array}{l}\text { My impression of this item is that in order to } \\
\text { be careful in doing things, the person should } \\
\text { act slowly. The words 'accurate' and 'slow' } \\
\text { imply two opposite meanings and make the } \\
\text { sentence difficult to understand. }\end{array}$ & $\begin{array}{l}\text { While I am fast, } \\
\text { I am careful } \\
\text { enough when } \\
\text { doing things. }\end{array}$ \\
\hline 94 & $\begin{array}{l}\text { I respond quickly to } \\
\text { visual and auditory } \\
\text { stimuli such as } \\
\text { sound and light. }\end{array}$ & $\begin{array}{l}\text { It sounds to me as being bothered by sound } \\
\text { and light. }\end{array}$ & $\begin{array}{l}\text { I use my senses } \\
\text { to be aware of } \\
\text { my } \\
\text { surroundings }\end{array}$ \\
\hline
\end{tabular}




\section{Discussion}

Cognitive interviewing was very helpful in optimizing scale items and significantly improved the clarity, comprehensibility, and quality of scale items. This study showed that finding the appropriate answer for each item involves a complex process of comprehension, information retrieval, judgment, and response (19). In this study, the items containing probable response errors were identified through cognitive interviews. In addition, the way respondents comprehend and interpret the items, along with tool problems were identified

Correct understanding of items by respondents is one of the important components in the cognitive interview process (5). This study showed that small changes in the appearance of the scale or words can lead to greater clarity in understanding items. According to COSMIN instructions, there is no reason to delete the item, but to improve the clarity of the item, words appropriate to the respondents' perception can be substituted (6). Research findings also indicate that scales designed with clear and unambiguous words for the target population, enable respondents to successfully answer the items $(24,25)$.

Most studies have reported that non-response to items of a scale occurs when the respondent is unable to understand the meaning of the item $(25,26)$. In cognitive interviewing, the process of responding to items is determined from the perspective of the respondents and the necessary corrections are made to the clarity the items, which leads to a reduction in non-response to items (26). In this study, participants had difficulty understanding some words and their meanings. It should be noted that the meaning of words should be considered in the context in which the scale is used. Words that are familiar to a group may be unfamiliar or have a different meaning for another group. Cognitive interviewing, facilitates understanding of the items and their interpretation by identifying problems of understanding the vocabulary of the scale for the respondents (27).

In this study, the participants had difficulty responding to items with negative words; this can confuse respondents in choosing a suitable option. Hence, in many studies, it has been recommended to avoid using negative words in the items as much as possible $(5,12)$.

\section{Limitation}

In our study, cognitive interview participants were selected from only three western provinces of Iran by purposive sampling. We may not have included the full range of all participants in the study.

\section{Conclusion}

Cognitive interviewing was effective in identifying problematic items in the Nursing Talent Identification Scale. Participants' feedback led to a significant improvement in the items of the scale. Although cognitive interview is a very time-consuming and costly, using it in the psychometric phase of the scale ensures that the Nursing Talent Identification Scale is a valid instrument for measuring the fit of nursing applicants for the characteristics of the professional. 


\section{Declarations}

\section{Acknowledgments}

The researchers would like to thank all participants in this study.

\section{Author's contribution}

FB: concept design, data collection, data analysis and interpretation, drafting of manuscript; AGH: participated in the study design, data collection and analysis, manuscript revision; LV: data collection, data analysis and interpretation; VZ: concept design, data collection, data analysis and interpretation, drafting of manuscript, manuscript revision. All authors read and approved the final manuscript.

\section{Funding}

This study was financially supporting by Tabriz University of Medical Sciences. The funding part had no role in the design of study, the collection, analysis and interpretation of data, or in writing the manuscript.

\section{Availability of data and materials}

The datasets used and/or analyses the current study are available from the corresponding author upon reasonable request.

\section{Ethics approval and consent to participate}

This study was approved by the Medical Ethics Committee of Tabriz University of Medical Sciences (Code: IR.TBMED.REC.1397.583). The study followed accepted ethical standards, as outlined in the Declaration of Helsinki. Before conducting the interviews, the purpose of the study was explained to the participants and a written informed consent was obtained. They were also assured that the recordings would be used anonymously, and that the recorded audio would be deleted after the conversation was transcribed, and their name would not be mentioned in the publications resulting from the study. Participants were free to refuse to continue the interview at any stage.

\section{Consent for publication}

Not applicable

\section{Competing interests}

The authors declare they have no competing interests.

\section{Author details}

${ }^{1}$ Department of Medical Surgical Nursing, School of Nursing and Midwifery, Tabriz University of Medical Sciences, Tabriz, Iran. ${ }^{2}$ Department of Pediatric Nursing, School of Nursing and Midwifery, Tabriz 
University of Medical Sciences, Tabriz, Iran.

\section{References}

1. Armstrong M. Armstrong's handbook of strategic human resource management. $13^{\text {th }}$ ed. London: Kogan Page; 2014.

2. Oladapo V. The impact of aptitude management on retention. Journal of business studies quarterly. 2014;5(3):19.

3. Gallardo-Gallardo E, Dries N, González-Cruz TF. What is the meaning of 'aptitude'in the world of work? Human Resource Management Review. 2013;23(4):290-300. https://psycnet.apa.org/doi/10.1016/j.hrmr.2013.05.002.

4. Potter, P. A., Perry, A. G., Hall, A., \& Stockert, P. A. Fundamentals of nursing. Ninth edition. St. Louis, Mo.: Mosby Elsevier; 2017.

5. Polit DF, Yang F. Measurement and the measurement of change: a primer for the health professions: Wolters Kluwer Philadelphia, PA; 2016.

6. Mokkink LB, Terwee CB, Patrick DL, Alonso J, Stratford PW, Knol DL, et al. The COSMIN study reached international consensus on taxonomy, terminology, and definitions of measurement properties for health-related patient-reported outcomes. Journal of clinical epidemiology. 2010; 63(7):737-45. https://doi.org/10.1016/j.jclinepi.2010.02.006

7. Polit DF, Beck CT. Nursing research: Generating and assessing evidence for nursing practice. 8 th ed. Philadelphia: Lippincott Williams \& Wilkins; 2008.

8. Ebadi A, Zarshenas L, Rakhshan M, Zareiyan A, Sharifnia S, Mojahedi M. Principles of measure development in health science. Tehran: Jame-e-negar; 2017.

9. Polit DF, Beck CT. Essentials of nursing research: Appraising evidence for nursing practice. 8th ed. Philadelphia: Wolters Kluwer Health /Lippincott Williams \& Wilkins;2014.

10. Denise F, Cheryl B. Essentials of nursing research: Appraising evidence for nursing practice. China: Lippincott Williams and Wilkins; 2013.

11. Rothman M, Burke L, Erickson P, Leidy NK, Patrick DL, Petrie CD. Use of existing patient-reported outcome (PRO) instruments and their modification: the ISPOR Good Research Practices for Evaluating and Documenting Content Validity for the Use of Existing Instruments and Their Modification PRO Task Force Report. Value in Health. 2009; 12(8):1075-83. https://doi.org/10.1111/j.1524-4733.2009.00603.x

12. Collins D. Cognitive interviewing: origin, purpose and limitations. Cognitive interviewing practice. London: SAGE; 2015:3-27. https://doi.org/10.4135/9781473910102

13. Patrick DL, Burke LB, Gwaltney CJ, Leidy NK, Martin ML, Molsen E, et al. Content validityestablishing and reporting the evidence in newly developed patient-reported outcomes (PRO) instruments for medical product evaluation: ISPOR PRO Good Research Practices Task Force report: 
part 2-assessing respondent understanding. Value in Health. 2011;14(8):978-88.

https://doi.org/10.1016/j.jval.2011.06.014

14. Willis GB, Miller K. Cross-cultural cognitive interviewing: Seeking comparability and enhancing understanding. Field methods. 2011;23(4):331-41. https://doi.org/10.1177/1525822X11416092

15. Willis GB. The practice of cross-cultural cognitive interviewing. Public opinion quarterly. 2015;79(S1):359-95. https://doi.org/10.1093/POQ\%2FNFU092

16. Beatty PC, Willis GB. Research synthesis: The practice of cognitive interviewing. Public opinion quarterly. 2007;71(2):287-311. https://doi.org/10.1093/poq/nfm006

17. Priede $C$, Farrall S. Comparing results from different styles of cognitive interviewing:'Verbal probing'vs.'thinking aloud'. International Journal of Social Research Methodology. 2011;14(4):27187. https://doi.org/10.1080/13645579.2010.523187

18. Willis GB, Artino Jr AR. What do our respondents think we're asking? Using cognitive interviewing to improve medical education surveys. Journal of graduate medical education. 2013;5(3):353. https://doi.org/10.4300/JGME-D-13-00154.1

19. Tourangeau R. Cognitive sciences and survey methods. Cognitive aspects of survey methodology: Building a bridge between disciplines. Washington, D.C.: National Academy Press;1984.15:73-100.

20. Tourangeau R, Rips LJ, Rasinski K. The psychology of survey response. Cambridge University Press;2000. https://doi.org/10.1017/CB09780511819322

21. D’Ardenne J. Developing interview protocols. Cognitive interviewing practice.London: SAGE; 2015:101-25. https://doi.org/10.4135/9781473910102

22. Ritchie J, Spencer L, Bryman A, Burgess R. Qualitative data analysis for applied policy research. Analyzing qualitative data.London: Routledge.1994;173:194. https://doi.org/10.4324/9780203413081

23. d'Ardenne J, Collins D. Data management. Cognitive interviewing practice. London: SAGE; 2015:14261. https://doi.org/10.4135/9781473910102

24. Moy P, Murphy J. Problems and prospects in survey research. Journalism \& Mass Communication Quarterly. 2016;93(1):16-37. https://doi.org/10.1177/1077699016631108

25. Pasick RJ, Stewart SL, Bird JA, D'Onofrio CN. Quality of data in multiethnic health surveys. Public Health Reports. 2001;116 SUPPL1 (SUPPL1).223-43. https://doi.org/10.1093/phr/116.s1.223

26. Ryan K, Gannon-Slater N, Culbertson MJ. Improving survey methods with cognitive interviews in small-and medium-measure evaluations. American Journal of Evaluation. 2012;33(3):414-30. https://doi.org/10.1177\%2F1098214012441499

27. Peterson $\mathrm{CH}$, Peterson NA, Powell KG. Cognitive interviewing for item development: Validity evidence based on content and response processes. Measurement and Evaluation in Counseling and Development. 2017;50(4):217-23. https://doi.org/10.1080/07481756.2017.1339564 